\title{
Physiological potential of soybean seeds under hypoxia and salinity stress
}

\section{Potencial fisiológico de sementes de soja sob condições de hipóxia e salinidade}

\author{
Carolina CHICHANOSKI'; Bruno Ribeiro FERREIRA²; Lia Mara MOTERLE³; \\ Renato Frederico dos SANTOS ${ }^{4}$
}

${ }^{1}$ Engenheira Agrônoma, Centro Universitário Ingá, carol_chichanoski@hotmail.com

2Engenheiro Agrônomo, Centro Universitário Ingá, brunowester@hotmail.com

${ }^{3}$ Autor para correspondência: Doutora em Produção Vegetal, Universidade Federal do Paraná. Rua Doutor João Maximiano, 426, Vila Operária Jandaia do Sul - PR, CEP: 86900-000, Imoterle@hotmail.com

${ }^{4}$ Doutorando em Produção Vegetal, Universidade Estadual de Maringá, agrorfs@hotmail.com

Recebido em: 03-07-2018; Aceito em: 11-02-2019

\begin{abstract}
Adverse factors affect the physiological performance of soybean seeds during field establishment. This study evaluates the physiological potential of Intacta soybean seeds under hypoxia and salinity stress, by submersion in water using different osmotic potentials. In both situations, three intact soybean cultivars (TMG 7062 IPRO, $63 i 64$ RSF IPRO, 7166 RSF IPRO) were tested in the laboratory. To test the effect of hypoxia, the seeds subjected to the tests were previously immersed in water for periods of $0,6,12,24$, and 48 hours. In the evaluation of salinity stress, towel papers were moistened with different solutions of potassium chloride $(\mathrm{KCl})(0.0 ;-0.4 ;-0.8$; and $-1.2 \mathrm{MPa}$ ). Seed germination and vigor (first germination count, shoot length, primary root length, and seedling dry biomass) were evaluated. Seed germination was negatively affected by the 12-hour period of hypoxia. Cultivars $763 i 64$ and 7166 were more tolerant to hypoxia conditions. Cultivar 7062 was more tolerant to salinity stress. Osmotic potential of $-0.4 \mathrm{MPa}$ affected the vigor of soybean seeds. Soybean cultivars showed adaptive differences under hypoxia and salinity stress.
\end{abstract}

Additional keywords: germination; [Glycine max (L.) Merril]; hypoxia; stress; vigor.

\section{Resumo}

A presença de fatores adversos afeta o desempenho fisiológico de sementes de soja durante o estabelecimento de campos de cultivo. O presente trabalho teve por objetivo avaliar o potencial fisiológico de sementes de soja Intacta sob efeito de condições de hipóxia e salinidade, por meio de submersão em água e condições variadas de potencial osmótico. Em ambas as situações, foram testadas, em laboratório, três cultivares de soja intacta (TMG 7062 IPRO, 63i64 RSF IPRO, 7166 RSF IPRO). Para testar o efeito das condições de hipóxia, as sementes submetidas aos testes foram previamente imersas em água pelos períodos de $0 ; 6 ; 12 ; 24$ e 48 horas. $\mathrm{Na}$ avaliação do estresse salino, os papéis-toalha foram umedecidos com diferentes soluções de cloreto de potássio (KCl) $(0,0 ;-0,4 ;-0,8$ e -1,2 MPa). Foram avaliados a germinação e o vigor das sementes (primeira contagem de germinação, comprimento da parte aérea e da raiz primária e biomassa seca de plântulas). A germinação das sementes foi afetada negativamente pelo período de 12 horas de hipóxia. As cultivares $763 i 64$ e 7166 foram mais tolerantes às condições de hipóxia. A cultivar 7062 foi mais tolerante ao estresse salino. $O$ nível de potencial osmótico de -0,4 Mpa afetou o vigor das sementes de soja. As cultivares de soja apresentaram diferenças adaptativas às condições de hipóxia e ao estresse salino.

Palavras-chave adicionais: estresse; germinação; [Glycine max (L.) Merril]; hipóxia; vigor.

\section{Introduction}

Soybean [Glycine max (L.) Merril] stands out as one of the main crops in Brazil due to its use both in human and animal feed, in addition to the production of derivatives for several industrial purposes.

Allied to the increase in productivity and the improvement of cultivars, according to the cultivation system, transgenic cultivars have stood out in the national agricultural scenario. The use of RR technology in soybean cultivation has brought attractive perspectives to the producer, such as less management techniques and improved yield, in addition to less costs in gross production revenue (Richetti, 2015).

Many factors have a broad spectrum in defining the production cost of a crop; however, some factors such as management, manpower, and mechanization are manipulated and avoided, while others are unalterable by human action; these are the edaphoclimatic factors present in each growing region. 
Among the edaphoclimatic factors, water is one of the main components in the agricultural context (Kirsanova et al., 2013), considering its importance in the transformation of energy into food (Taiz \& Zeiger, 2017) and in seed germination (Marcos-Filho, 2015).

The variation in the amount of soil water is considered one of the most common causes of yield loss. Hypoxia conditions tend to cause reduced oxygen availability to the roots due to the occupation of the total soil porosity by water and the slow diffusion of oxygen by water (Zabalza et al., 2008), which may affect the growth of different plant species (Ramos et al., 2010; Coelho et al., 2013; Rosa et al., 2015).

Negative effects of hypoxia in yield are also related to decreased seed germination and losses in the initial planting of seedlings (Gazolla-Neto et al., 2012), since water oscillations are quite frequent during sowing times (Marcos Filho, 2015).

During the germination process, the supply of energy and organic substances that support the growth of the embryo occurs by increased seed respiration, which depends on the increase of the degree of hydration of its tissues (Carvalho \& Nakagawa, 2012). Oxygen is necessary for oxidation of reserve materials and for energy supply for the development of the embryonic axis. Notwithstanding, excessively humid soils limit oxygen availability, favoring the production of ethanol in the cells, which is toxic to the normal metabolism. Thus, under certain conditions of excessive rainfall, soon after sowing, this factor can be limiting to production, causing seed deterioration and leading to lesser emergence of seedlings in the field (Gazola-Neto et al., 2012).

Many studies have shown changes in germination percentage and in the initial morphophysiological characteristics of several species when subjected to hypoxia, including white oats (Rosa et al., 2015), beans (Custódio et al., 2002; Custódio et al., 2009; Pedó et al., 2017), maize (Dantas et al., 2000; Gazola et al., 2014), and soybean (Gazolla Neto et al., 2012). Moreover, the seed survival rate may show varietal differences after some flooding levels (Gazola et al., 2014; Pedó et al., 2017).

On the other hand, in addition to the damage caused by excess water, damage to seed germination may occur due to soil salinity in certain regions. Salinity stress acts osmotically, hindering water absorption by the roots (Lopes \& Macedo, 2008) or favoring the entry of ions into the cells (Moraes \& Menezes, 2003).

Water potential is defined as the transfer of water from the highest to the lowest level, until reaching the necessary balance at the seed imbibition stage in the germination process (Marcos Filho, 2015). The more negative the water potentials in the initial stage of imbibition, the longer the reorganization of structures, with retardation or prevention of seedling growth.

Common practical situations with harmful negative potentials for seed germination in soybean expansion areas coincide with saline soils due to low rainfall, high water deficit, and even inadequate irrigation
(Soares et al., 2015).

In salinity stress conditions simulated by $\mathrm{NaCl}$, research reported decreased seed germination and initial vigor in radish, "pau-fava" (Pereira et al., 2014), beans (Dalchiavon et al., 2016), maize (Silva et al., 2016), and soybean (Carvalho et al., 2012; Shu et al., 2017). In soybean seeds, the reduction of osmotic potential with $\mathrm{NaCl}$ reduces the $\mathrm{GA} / \mathrm{ABA}$ ratio, affecting germination (Shu et al., 2017).

In addition to $\mathrm{NaCl}$, potassium chloride $(\mathrm{KCl})$ is also considered an efficient osmotic agent in salinity stress simulation. In soybean and crotalaria, germination and plant growth were significantly reduced with increasing $\mathrm{KCl}$ concentration in the solution (Moraes \& Menezes, 2003; Nunes et al., 2009). Potassium chloride $(\mathrm{KCl})$ is soluble and harmful, causing toxicity when absorbed with water, leading to physiological disturbances and decreased germination potential (Lima et al., 2001).

However, it should be noted that there is a lack of studies that address the performance of soybean seeds under environmental adversities, especially when related to hypoxia and soil salinity. Information on these aspects are relevant to advances in science and technology as well as to subsidize the choice of materials best suited to the different types of production environments. In this sense, this study evaluates the effects of hypoxia and salinity stress on germination and vigor of soybean cultivars.

\section{Materials and methods}

The present study was conducted in the Laboratory of Seed Technology. Two experiments (1 and 2) were performed separately: 1) submersion of seeds in water to simulate hypoxia conditions; and 2) salinity stress caused by $\mathrm{KCl}$. For that purpose, three Intacta soybean seeds (TMG 7062 IPRO, 63i64 RSF IPRO, 7166 RSF IPRO) from the 2015/2016 harvest were used, each represented by one lot.

During the experimental period, the seeds were stored in Kraft paper bags, in an airy place with an average temperature of $\pm 22^{\circ} \mathrm{C}$. Prior to the evaluated treatments, the seeds were treated with the fungicide Vitavax-Thiram $200 \mathrm{SC}$ at $3 \mathrm{~mL} \mathrm{~kg}^{-1}$ seeds.

\section{Experiment 1 - Hypoxia conditions}

The experiment was carried out in a $3 \times 5$ factorial arrangement (cultivars $x$ immersion times). To induce water excess, we used the method consisting of water immersion for $6,12,24$, and 48 hours, in addition to the control (without hypoxia), at $25^{\circ} \mathrm{C} \pm 2{ }^{\circ} \mathrm{C}$. Seeds were submerged in $100 \mathrm{~mL}$ distilled water in $250 \mathrm{~mL}$ plastic cups, each cup containing 100 seeds, using 4 cups per treatment. To prevent bacterial proliferation, bactericidal Ampicillin was added to the hypoxic solution, at $150 \mathrm{mg} \mathrm{L}^{-1}$ water.

After the periods of hypoxia, seeds were subjected to the germination test, in which four subsamples of 50 seeds from each treatment were distributed 
on two sheets of germitest paper towels moistened with water in a volume equivalent to 2.5 times the mass of dry substrate. The seeds were then covered with a sheet. Subsequently, germination rolls were prepared, which were kept in a Mangelsdorf germinator at $25^{\circ} \mathrm{C} \pm 2{ }^{\circ} \mathrm{C}$. The first and final count of germination were determined according to the Rules for Seed Analysis, at 5 and 8 days after sowing, respectively, and the results expressed in percentages (Brasil, 2009)

Seedling root and shoot length were evaluated according to Nakagawa (1999). Ten seeds were distributed longitudinally in a row in the upper third of the premoistened substrate paper. Subsequently, rolls similar to those of the germination test were made (Brasil, 2009), using five replicates per treatment. The rolls were taken to the germinator for seven days, following the procedures described for the germination test. The measurements were performed after this period, with results expressed in $\mathrm{cm}$ seedling ${ }^{1}$.

To obtain the dry biomass, seedlings whose cotyledons were previously removed in the length test were packed in paper bags and taken to an oven with air circulation at $80^{\circ} \mathrm{C}$ for 24 hours. This period was sufficient to reach a constant mass, by means of successive weighings. The results were expressed as mg seedling ${ }^{-1}$.

The experimental design was completely randomized in a factorial arrangement. The results of the experiment were submitted to analysis of variance and the means were compared by the Tukey test, for cultivars; and by regression analysis, to verify the behavior of variables as a function of hypoxia duration (hours), for each cultivar, at $5 \%$ probability level. Regression equations were fitted to second-degree polynomials, and those with the highest coefficient of determination $\left(R^{2}\right)$ were chosen. The Sisvar software was used for statistical analysis (Ferreira, 2011).

\section{Experiment 2 - Salinity stress}

The experiment was carried out in a $3 \times 4$ factorial arrangement (cultivars $\times$ osmotic potentials). Potassium chloride $(\mathrm{KCl})$ solutions were used to induce water deficit. Osmotic potentials (MPa) and respective $\mathrm{KCl}$ concentrations (g. $\left.\mathrm{L}^{-1}\right)$ used were: zero $(0.0) ;-0.4$ $(6.62 \mathrm{~g}) ;-0.8$ (13.24 g); -1.2 MPa (20.07 g). The potential $0.0 \mathrm{MPa}$ corresponded to the control (control), whose substrate (filter paper) was moistened with distilled water. For the calculation of the amount of $\mathrm{KCl}$ to be added to obtain each tension, the formula of Van't Hoff, quoted by Salisbury \& Ross (1991), was used: Yos = - RTC, where: Yos = osmotic potential (atm); $\mathrm{R}=$ universal constant of perfect gases (0.082 atm mol L-1 $\left.\mathrm{K}^{-1}\right) ; \quad \mathrm{T}=$ temperature $(\mathrm{K})$; $\mathrm{C}=$ concentration $\left(\mathrm{mol} \mathrm{L}^{-1}\right) ; \mathrm{mol} \mathrm{L}^{-1} \times$ molar mass of $\mathrm{KCl}=\mathrm{g} \mathrm{L}^{-1}$ and $\mathrm{T}(\mathrm{K})=273+\mathrm{T}\left({ }^{\circ} \mathrm{C}\right)$.

To evaluate the physiological quality of seeds, the tests used in experiment 2 were the same as those used in the experiment to evaluate the effect of hypoxia conditions. However, the paper towel used to prepare the rolls was previously moistened with the solutions mentioned above.

The experimental design was completely randomized in a factorial arrangement. The results of the experiment were submitted to analysis of variance and the means were compared by the Tukey test, for cultivars; and by regression, to verify the behavior of variables as a function of osmotic potential, for each cultivar, at 5\% probability level. The Sisvar software was used for statistical analysis (Ferreira, 2011).

\section{Results and discussion}

Analysis of variance $(P<0.05)$ showed significant effects for the interaction between cultivars and hypoxia durations or osmotic potentials for most of the studied variables, meaning that cultivars behaved differently as a function of hypoxia periods and salinity levels.

The results of the final germination count did not differ significantly between cultivars in the periods of zero and six hours (Figure 1A). However, cultivar 7062 showed lower resistance to the stress condition when seeds were subjected to longer periods of hypoxia (12, 24 , and 48 hours), with results coinciding with the first count (Figure 1B). These results can be explained by the reduction of seed germination rate and percentage, caused by water excess, which prevents oxygen penetration and reduces the metabolic process (Zabalza et al., 2008).

Similarly, Dantas et al. (2000) also observed differences in sensitivity among maize genotypes under periods of hypoxia. In their study, the authors mentioned that excessive imbibition of water by the seed can cause rupture of cell membranes, leaching of electrolytes, sugars, amino acids, and lead to a lower efficiency of anaerobic enzymes in less tolerant species. Thus, toxic substances produced under conditions of hypoxia may have caused the greater decrease in germination. Cultivar 7062 was more sensitive to the effects of these substances.

Regarding the performance as a function of hypoxia periods (Figure 1A), the germination values of the three cultivars decreased with increasing periods of hypoxia, but there was no total inhibition, even in the longest period (48 hours).

For cultivars 7062 and 7166, quadratic equations were fitted according to periods of hypoxia. Thus, hypoxia periods of 36.6 and 32.51 hours led to the minimum germination rates of 39.5 and $63.0 \%$, respectively. The linear behavior presented by cultivar $63 i 64$ indicates a decrease of $0.57 \%$ in the germination of this cultivar for each unit of variation in time, that is, for each additional hour of the period of hypoxia. Such observations indicate the deleterious effect of hypoxia on early seedling development, and this reduction is probably associated with the stress caused by increased hypoxia. Oxygen availability is limited during submersion (Zabalza et al., 2008), with water entering the seed quickly and in large quantities due to the dif- 
ference in the water potential between the seed and the medium, causing damage due to imbibition (Costa et al., 2008). Furthermore, cultivars direct their meta- bolism to circumvent stress conditions, thus the energy expenditure to adapt to this stress is higher than that of germination itself (Vaz-de-Melo et al., 2012).

A

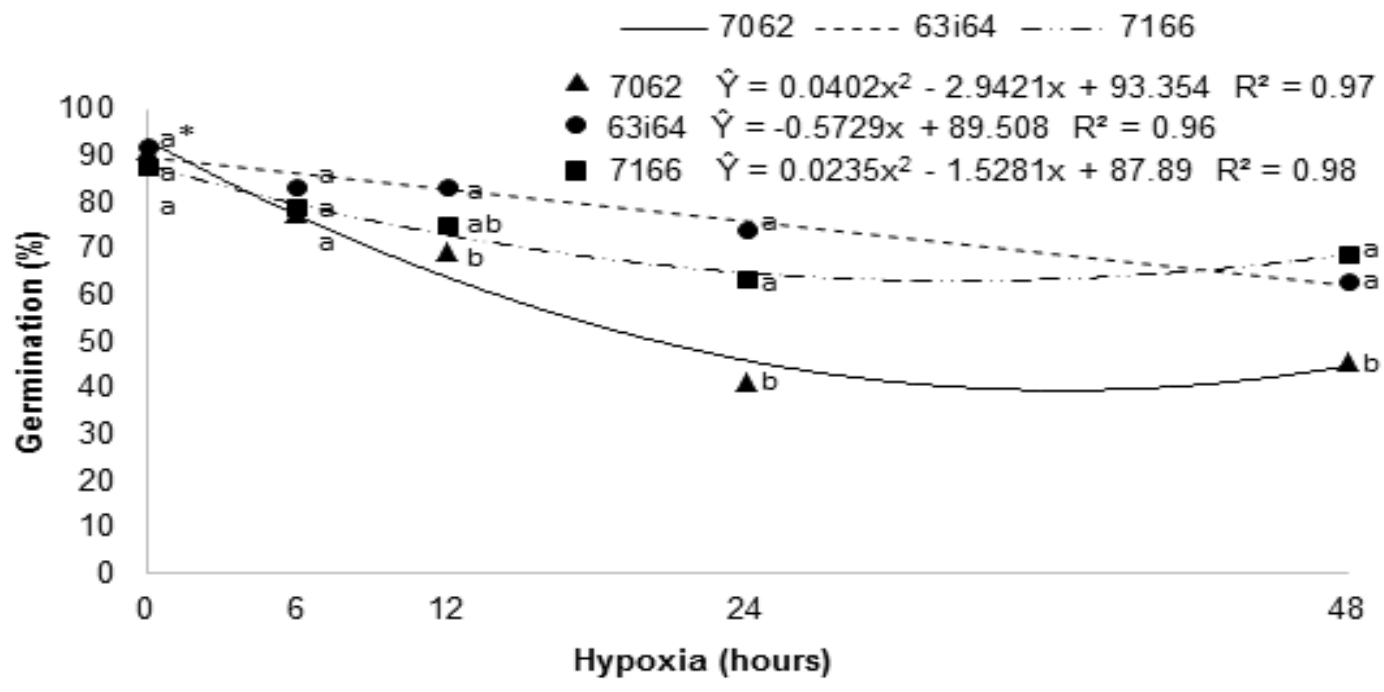

B

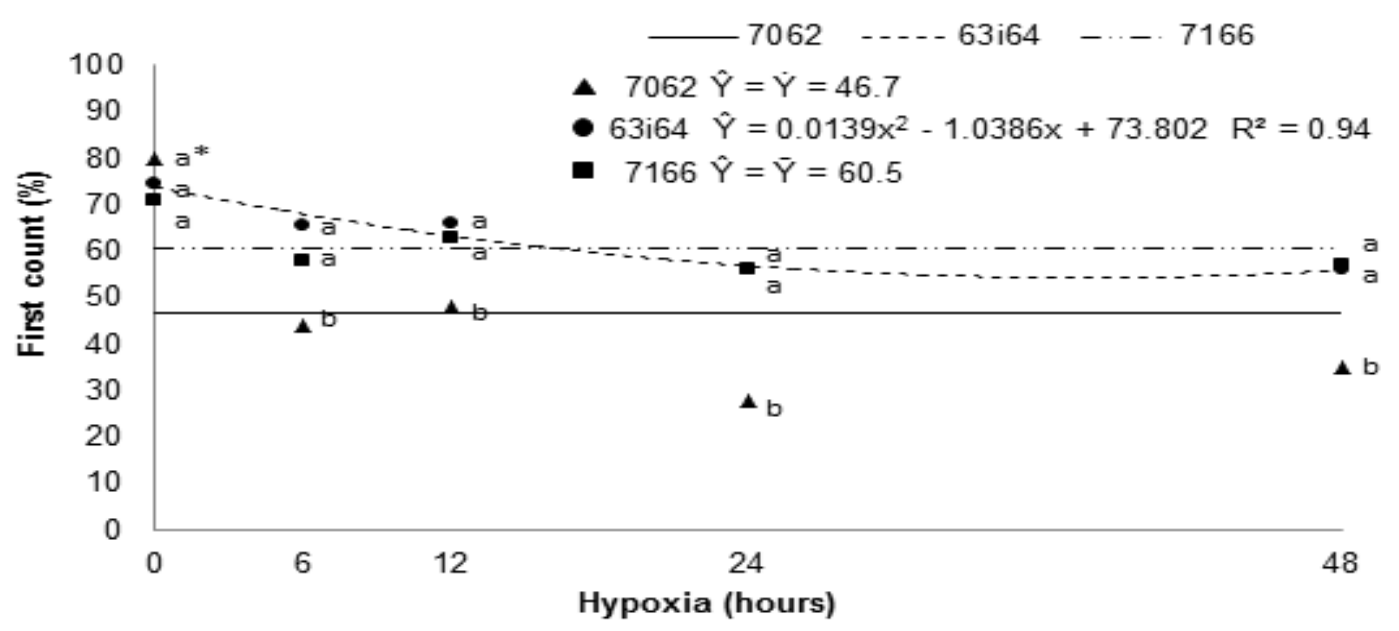

Figure 1 - Percentage of normal seedlings in the final count $(A)$ and first count $(B)$ of the seed germination test of three soybean cultivars submitted to five hypoxia periods. *Means followed by the same letter in the column do not differ from each other by the Tukey test, at a 5\% probability level.

In the first count of the germination test (Figure $1 \mathrm{~B})$, only cultivar $63 i 64$ fitted the regression equation, in which increasing periods of seed hypoxia decreased the percentage of normal seedlings. For this variable and cultivar, it was possible to fit the quadratic regression equation according to periods of hypoxia, in which the period of 37.36 hours led to the minimum percentage of normal seedlings of $54.4 \%$. These results were in part similar to those presented by Custódio et al. (2002), when studying bean seeds. The authors observed an increase in the percentage of dead seeds and abnormal seedlings, and a reduction in the percentage of normal seedlings under periods of hypoxia. However, this reduction was quite drastic above eight hours of submersion in water, contrary to the results obtained in the present study. Hence, although there may have been a reduction in the percentage of normal seedlings, this reduction was not extremely negative. This corroborates the results obtained by Gazola et al. (2014), who verified that variations in the periods of hypoxia (32 and 49 hours) were beneficial to the increase of the percentage of normal seedlings in the first germination count of maize seeds.

Probably, as emphasized by Vaz-de-Melo et al. (2012), water acted as a stimulating/controlling agent during the germinative process, since it promotes softening of the integument, favoring oxygen penetration and increased volume of the embryo and reserve tissues. 
Regarding the evaluation of primary root length, shoot length, and dry biomass of seedlings (Figure 2), the results were in contrast to those of germination. Cultivar 7166 stood out for shoot length in smaller periods of hypoxia. For dry biomass, in turn, cultivar 7062 outperformed the others, except for the 24-hour period, in which there was no difference between the evaluated cultivars (Figure $2 \mathrm{C}$ ).

A

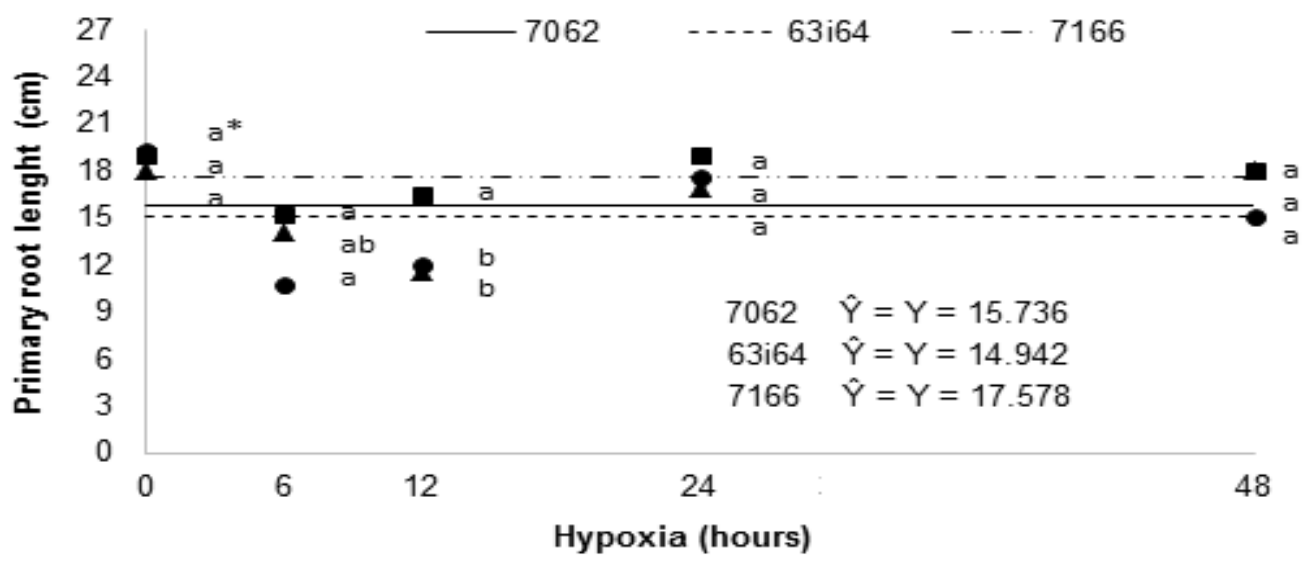

B

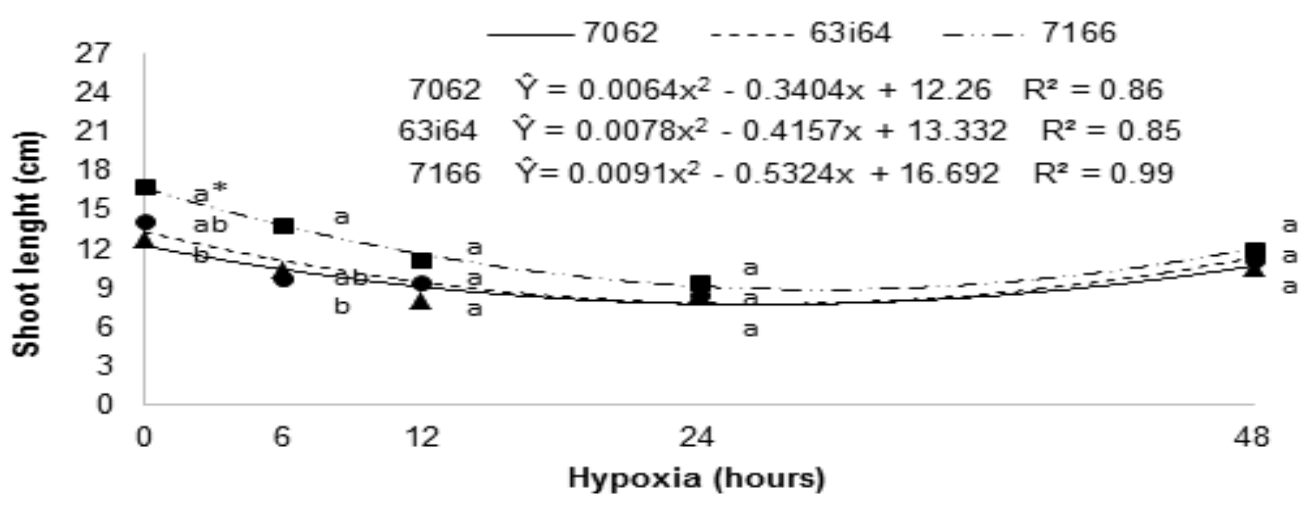

C

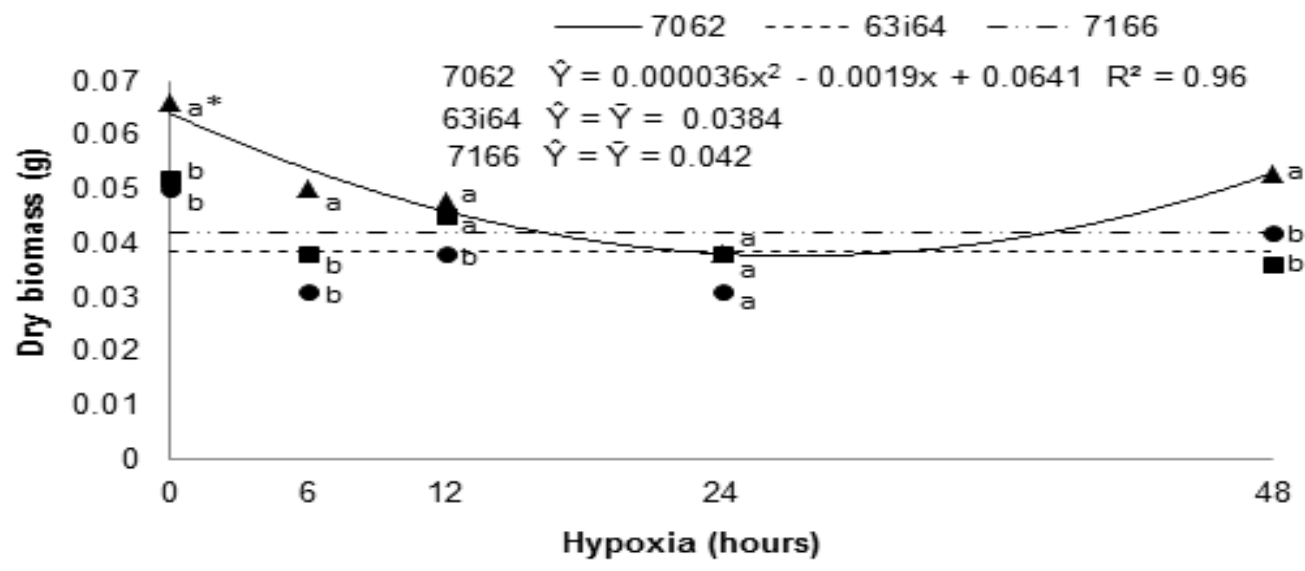

Figure 2 - Primary root (A) and shoot (B) lenght and dry biomass (C) of the seedlings of three soybean cultivars, submitted to five hypoxia periods. *Means followed by the same letter in the column do not differ from each other by the Tukey test, at a $5 \%$ probability level. 
For the primary root length of soybean cultivars, regression adjustment was not possible (Figure 2A). These results were different from those obtained by Carvalho et al. (2012), when comparing the germination and development of conventional and transgenic soybean seedlings under adverse conditions. According to the authors, in this situation, seedlings show greater root development to circumvent the effects of lack of oxygen. The three cultivars analyzed had a marked reduction in shoot growth up to the 24-hour period (Figure 2B). For this variable, it was possible to fit quadratic equations as a function of hypoxia periods for the three cultivars (7062, 63i64, and 7166) evaluated. Therefore, to hypoxia periods of 26.6, 26.6, and 29.2 hours, the minimum shoot length obtained was 7.7, 7.8, and $8.9 \mathrm{~cm}$, respectively. Thus, for this variable, cultivar 7166 was less affected by hypoxia compared to the others. In general, these results are similar to those verified by Custódio et al. (2002) in bean seeds, in which there was a drastic reduction in shoot biomass in the first hours of submersion in water, becoming constant in the other periods.

These results corroborate those verified by Dantas et al. (2000) in a study performed with maize seeds, in which the authors verified that despite the general decrease in germination and vigor of seeds subject to flood, the seeds that survived showed greater individual vigor in relation to the others, translated by seedling shoot and primary root growth.

For seedling dry biomass (Figure 2C), it was possible to fit the quadratic regression equation for cultivar 7062 as a function of hypoxia periods, in which the period of 26.4 hours led to the minimum seedling dry biomass of 0.039 grams. The other cultivars did not fit the regression equation. The effect of hypoxia on seedling dry biomass of cultivar 7062 was similar to that observed on shoot length, in which there was an increased development in the longest period of hypoxia.

These results disagree with those obtained by Batista et al. (2008) and Custódio et al. (2002), who noted that longer hypoxia periods negatively affect the dry matter accumulation of cultivars, a fact associated to the decreased growth of some organs during flooding, being a strategy to save energy and maintain a minimum functioning of the metabolism in the regions most affected by hypoxia. Notwithstanding, the results agree with Dantas et al. (2000), who verified an increased dry biomass in the early development of maize seedlings with increasing flooding days. According to the authors, this fact occurred due to the greater individual vigor of the seeds that survived these conditions, and was translated by shoot growth and seedling dry biomass. Similarly, Gazola-Neto et al. (2012), when testing the effect of increasing water content on the initial growth of soybean seedlings, also noticed a tendency of flooded seedlings to allocate a greater amount of dry matter in the roots and a smaller amount in the shoots compared to non-flooded seedlings. Thus, in the present study, probably the increase of biomass occurred due to both the increase in the amount of secondary roots as a defense mechanism to the lack of oxygen in the rhizosphere and the greater vigor of the seeds that survived.

The results for the percentage of normal seedlings in the germination and first germination count tests and primary root length as a function of osmotic potentials are shown in Figure 3. A descriptive analysis was used, with representation of the standard deviations, since the results did not allow the adjustment of regression equations for these three characteristics.

Regarding the performance of cultivars under different osmotic potentials, the germination and first count of cultivar 7062 exceeded the others at $-0.8,-1.2$, and $-0.4,-0.8 \mathrm{MPa}$, respectively (Figure $3 \mathrm{~A}$ and $3 \mathrm{~B}$ ).

As for germination, obtained as a function of different osmotic potentials (Figure $3 \mathrm{~A}$ ), the percentage of normal seedlings decreased for the three cultivars evaluated. Significant reductions in seed germination were also observed in the study of Nunes et al. (2009), Carvalho et al., (2012), Melloni et al. (2012), and Pereira et al. (2014). These results prove the harmful effects of salinity stress due to its osmotic or ionic impact, impairing the absorption of water or favoring the entry of ions into the cells (Braccini et al., 1996). Shu et al. (2017) reported that salinity stress causes oxidative stress and represses the germination of soybean seeds by negatively regulating gibberellic acid biosynthesis.

However, it is important to emphasize that the three evaluated cultivars were resistant to water deficit, which could be verified at the highest potential, that is, $-1.2 \mathrm{MPa}$. Similarly, Lopes \& Macedo (2008) and Deuner et al. (2011) reported a certain tolerance of Chinese cabbage and kidney beans, respectively, to salinity stress, with a marked reduction in germination only at higher concentrations. In turn, when studying the germination behavior of maize seeds, Silva et al. (2016) reported that seed germination was less affected by the presence of salt than root growth.

For the percentage of normal seedlings in the first count, the three cultivars responded negatively to the reduction of osmotic potential levels, reaching a nil value at $-1.2 \mathrm{MPa}$ (Figure 3B). This behavior was also reported by Moterle et al. (2006) in studies with popcorn maize, although nil seed germination was already observed at higher potentials $(-0.6 \mathrm{MPa})$. The results suggest that the toxic effects of salts caused inhibition of germination. These results have been attributed to the reduction of the amount of water absorbed by the seeds in saline medium, with reduction of the osmotic potential of the solutions (Braccini et al., 1996; Carvalho et al., 2012; Melloni et al., 2012).

Contrary to that obsenved for germination in the most negative potential, i.e., $-1.2 \mathrm{MPa}$, cultivar 7062 differed significantly from cultivar 7166 for shoot length (Figure 4A). Thus, it is noteworthy that, even if germination was better for cultivar 7062, its seed vigor was affected by the stress that occurred in the early development. This result was also observed by Moterle et al. (2006) in seeds of popcorn maize cv. BRS-Angela, at $-0.3 \mathrm{MPa}$ 
A

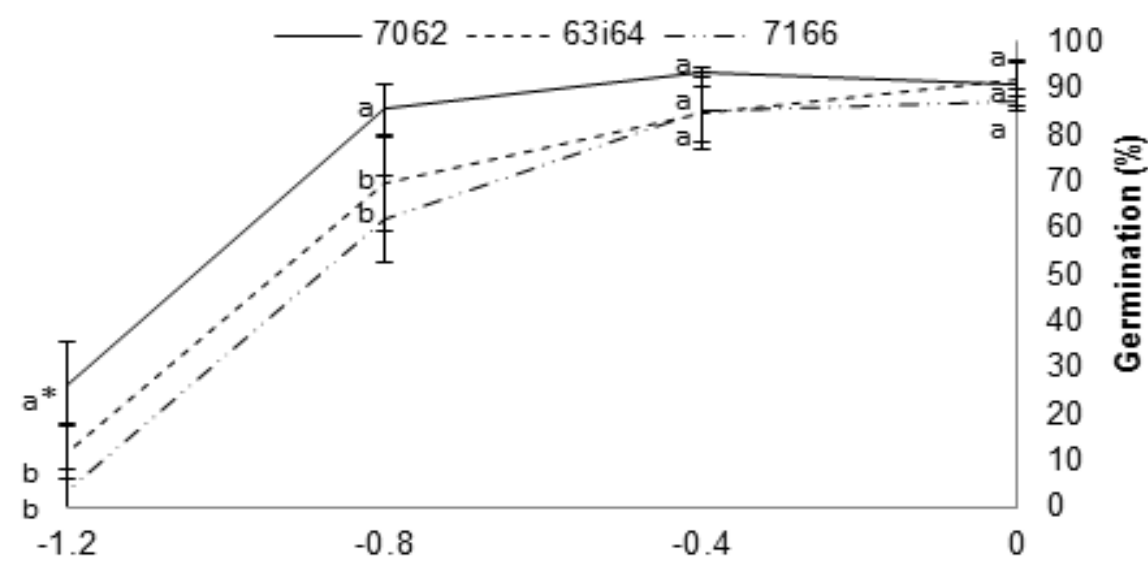

Osmotic potential (MPa)

B

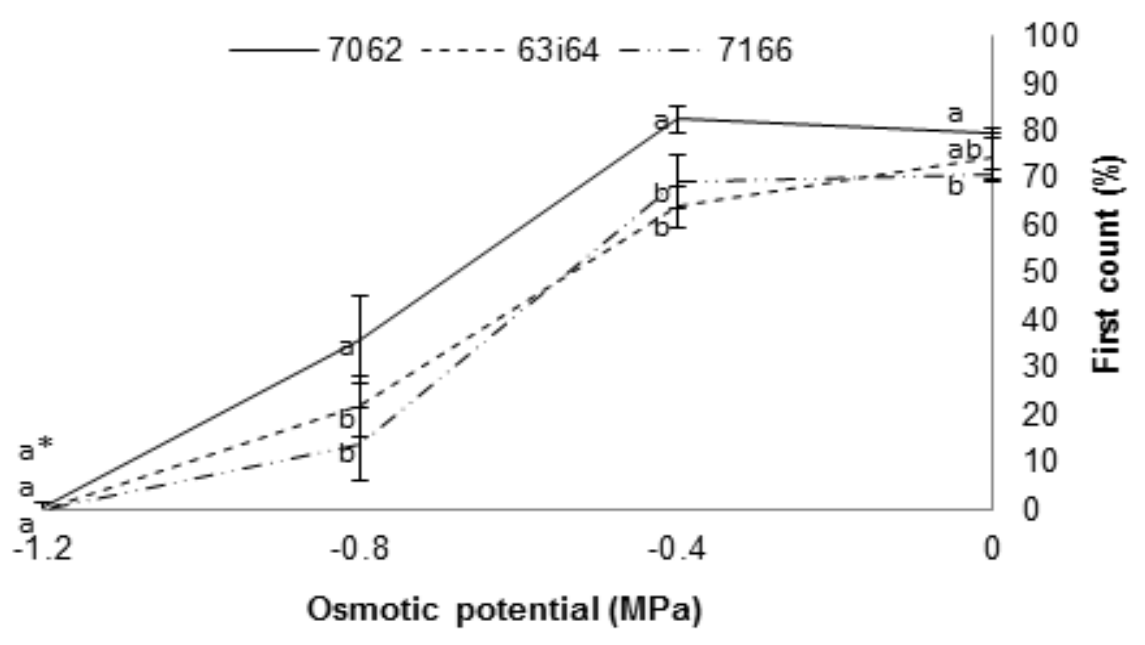

C

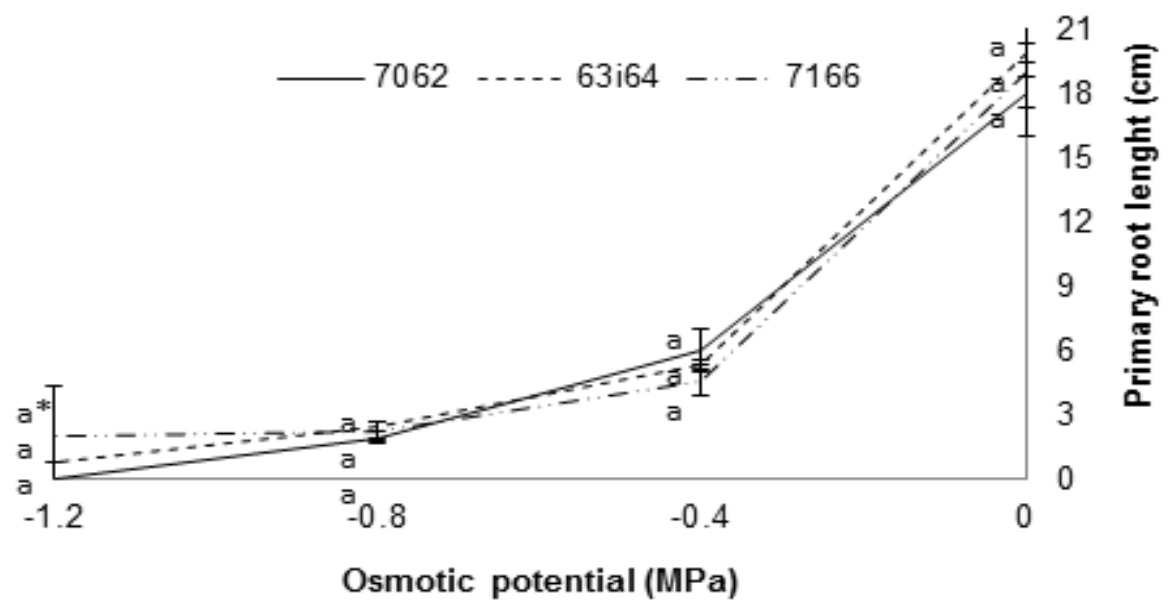

Figure 3 - Percentage of normal seedlings in the final count $(A)$ and first count $(B)$ of the seed germination test and primary root length $(\mathrm{cm})$ of the seedlings of three soybean cultivars submitted to four levels of osmotic potential in $\mathrm{KCl}$ solution. *Means followed by the same letter in the column do not differ from each other by the Tukey test, at a $5 \%$ probability level. 
A

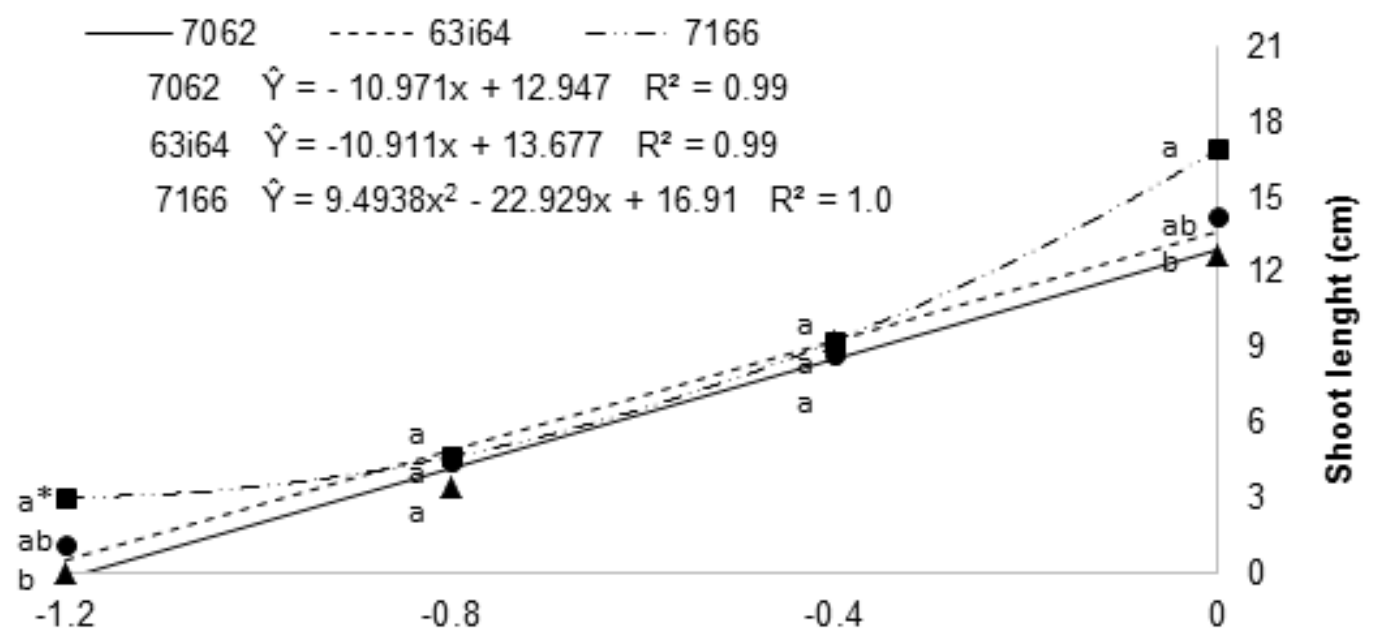

Osmotic potential (MPa)

B

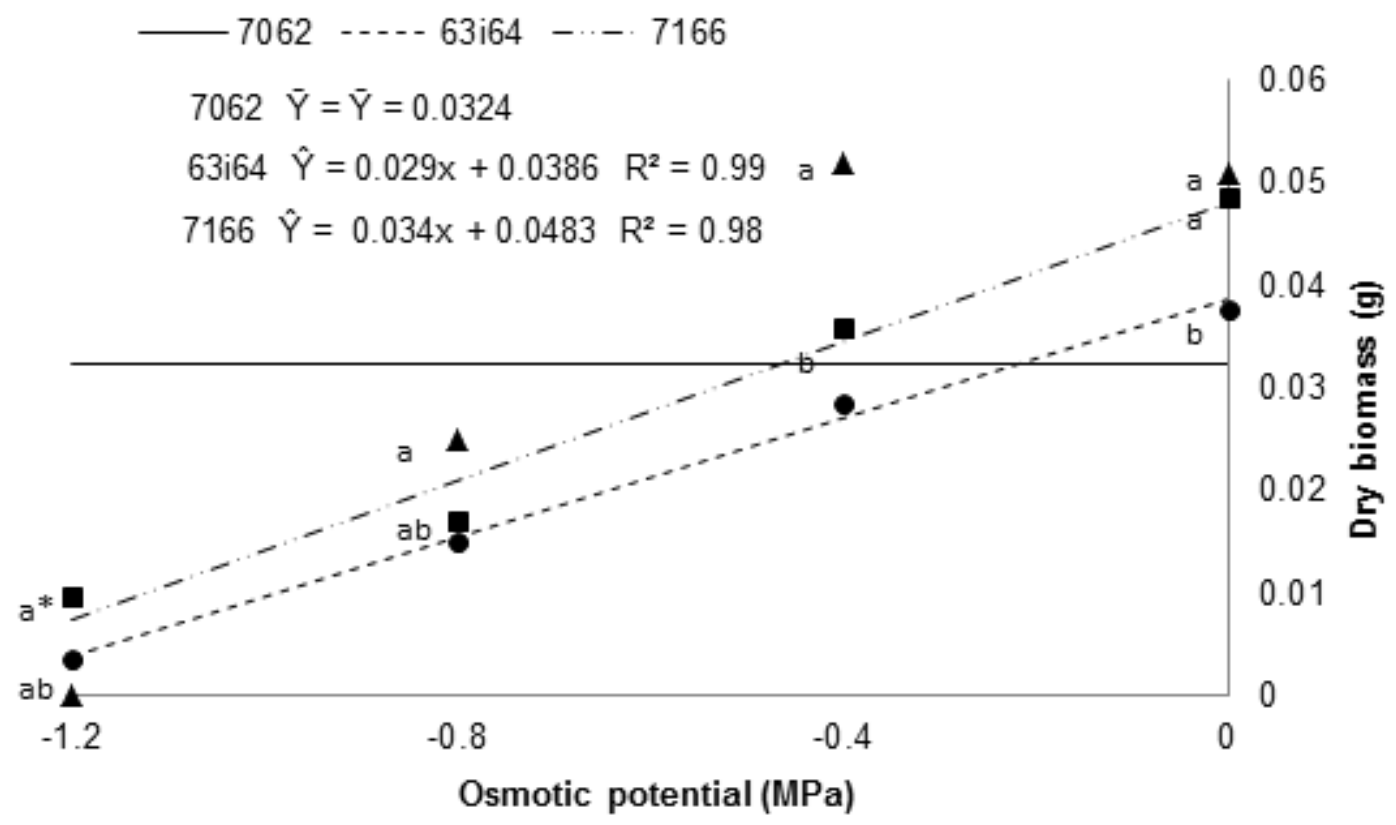

Figure 4 - Shoot length (A) and dry biomass (B) of the seedlings of three soybean cultivars, submitted to four levels of osmotic potential in $\mathrm{KCl}$ solution. *Means followed by the same letter in the column do not differ from each other by the Tukey test, at a $5 \%$ probability level.

The root and shoot length of cultivars decreased for all potentials when compared to the control $(0.0$ $\mathrm{MPa}$ ) (Figure $3 \mathrm{C}$ and $4 \mathrm{~A}$ ). In the evaluation of primary root growth (Figure $3 \mathrm{C}$ ), cultivars showed a drastic reduction up to the osmotic potential of $-0.4 \mathrm{MPa}$. With the induction of more negative osmotic potentials $(-0.8$ and $-1.2 \mathrm{MPa}$ ), cultivars $63 \mathrm{i} 64$ and 7166 stabilized the growth and reduction of the primary root. Similar results were also evidenced by Carvalho et al. (2012) in soybean seeds, and by Silva et al. (2016) in maize seeds. Primary root stabilization in these cultivars can be explained by the fact that they try to circumvent stress situations so as to increase water intake. Plants with a more developed root system tend to be more resistant to water stress because, in this situation, leaf expansion is regulated by root water (Toorchi et al., 2009).

On the other hand, the results of Figure $4 \mathrm{~A}$ show that for each unit of variation in the osmotic potential, that is, $1.0 \mathrm{MPa}$ reduction, the shoot length 
decreases by $10.97 \mathrm{~cm}$ (angular coefficient) for cultivar $63 i 64$ and $10.91 \mathrm{~cm}$ for cultivar 7062. The results obtained for the mentioned variable corroborate those observed in the literature, in which different crops showed a marked reduction of seedling shoot length with increasing salt concentrations in the substrate (Soares et al., 2015; Silva et al., 2016; Viçosi et al., 2017). This decrease in growth probably occurred due to the reduction of cell expansion. Under water stress conditions, such reduction is considered the first measurable effect (Taiz \& Zeiger, 2017). As pointed out by Soares et al. (2015), salinity stress negatively affects the mobilization of seed reserves to the seedling, affecting its growth.

For cultivar 7166, shoot length was fitted to a quadratic equation as a function of osmotic potentials (Figure 4A). Thus, osmotic potential reduction to $-1.2 \mathrm{MPa}$ led to the minimum shoot length of $3.1 \mathrm{~cm}$. These results highlight the superiority of this cultivar, since it tried to overcome the lack of water in more negative potentials by activating its metabolism to maintain the morphological growth structure. Similarly, Carvalho et al. (2012) also found differences in salt stress sensitivity among soybean cultivars. Under stress conditions, plants tend to maintain osmotic pressure by accumulating inorganic solutes in the vacuole and organic solutes in the cytoplasm, allowing them to tolerate more negative potentials (Taiz \& Zeiger, 2017).

When comparing the biomass of cultivars, cultivar 7062 stood out at -0.4 and $-0,8 \mathrm{MPa}$. However, at the highest potential, i.e., -1.2 MPa, cultivar 7166 was significantly superior to 7062 (Figure 4B).

The dry biomass of soybean cultivars $63 i 64$ and 7166 decreased with decreasing osmotic potentials (Figure 4B). For each unit of variation in the osmotic potential, the biomass decreases by $0.029 \mathrm{~g}$ (angular coefficient) for cultivar $63 \mathrm{i} 64$ and $0.034 \mathrm{~g}$ for cultivar 7062. In this case, when comparing cultivars, cultivar 7062 showed a larger average reduction in seedling dry biomass.

Similar results, with reduction in cell expansion and dry biomass production, were also observed by Braccini et al. (1996) and Soares et al. (2015) in soybean seeds, and by Dalchiavon et al. (2016) in bean seeds. Therefore, at higher levels of salt stress, the distribution of seed reserves to the tissues was probably altered, a fact that influenced the lower dry biomass accumulation.

By analyzing the variables related to seedling growth, which decreased with decreasing osmotic potentials, it was possible to prove the consequences of salt stress in the initial period of crop establishment. These results corroborate those obtained by Moraes \& Menezes (2003), Teixeira et al. (2008), and Soares et al. (2015) in soybean. Water stress slows physiological and biochemical processes, thereby restricting development (Moraes \& Menezes, 2003). Similarly, as found by Carvalho et al. (2012), under water stress conditions, seedlings tend to direct their reserves for root development as their tissues pass through salt or water stress, being this an adaptive mechanism of the plant to the adversities of the environment in which it is inserted (Taiz \& Zeiger, 2017).

In general, under hypoxia conditions, cultivars $63 i 64$ and 7166 performed better than 7062 (Figure 1) for the variables normal seedlings in the first count and final germination count. However, for $\mathrm{KCl}$-induced stress, the same cultivars performed worse than 7062 (Figure 3). For the other variables, the results obtained also differed, in which each cultivar expressed its genetic characteristics, being predominant in different variables. Probably, these cultivars manifested their resistance, inherited from their genotype, to overcome the different conditions of water supply. The differentiation between cultivars in the studied variables can be explained by the genetic constitution of each one. Genotypes differ as for their physiological quality, thus expressing quite different results in salt stress conditions (Braccini et al.,1996; Moterle et al., 2006; Soares et al., 2015) and in the initial development of seeds under hypoxia conditions (Gazola et al., 2014; Silva et al., 2016).

Notwithstanding, according to the present study, soybean cultivars have adaptive differences, which are evident even within transgenic genotypes. This fact determines seed performance in the face of environmental stresses. Thus, new studies are needed to evaluate the behavior of different materials under unfavorable environmental conditions.

\section{Conclusions}

Seed germination was negatively affected by the 12-hour period of hypoxia.

Cultivars $763 i 64$ and 7166 were more tolerant to hypoxia conditions.

Cultivar 7062 was more tolerant to salinity stress. Osmotic potential of $-0.4 \mathrm{MPa}$ affected the vigor of soybean seeds.

Soybean cultivars showed adaptive differences under hypoxia and salinity stress.

\section{References}

Batista CUN, Medri ME, Bianchini E, Medri C, Pimenta JA (2008) Tolerância à inundação de Cecropia pachystachya Trec. (Cecropiaceae): aspectos ecofisiológicos e morfoanatômicos. Acta Botânica Brasileira 22(1):91-98.

Braccini AL, Ruiz HA, Braccini MCL, Reis MS (1996) Germinação e vigor de sementes de soja sob estresse hídrico induzido por soluções de cloreto de sódio, manitol e polietileno glicol. Revista Brasileira de Sementes 18(1):10-16.

Brasil (2009) Ministério da Agricultura, Pecuária e Abastecimento. Regras para análise de sementes / Ministério da Agricultura, Pecuária e Abastecimento. Secretaria de Defesa Agropecuária. - Brasília: Mapa/ACS, 399p. 
Carvalho NM, Nakagawa J (2012) Semente: ciência, tecnologia e produção. Funep. 590p.

Carvalho TC, Silva SS, Silva RC, Panobianco M (2012) Germinação e desenvolvimento inicial de plântulas de soja convencional e sua derivada transgênica RR em condições de estresse salino. Ciência Rural 42(8):1366-1371.

Coelho CCR, Neves MG, Oliveira LM, Conceição AGC, Okumura RS, Oliveira Neto CF (2013) Biometria em plantas de milho submetidas ao alagamento. Agroecossistemas 5(1):32-38.

Costa CJ, Villela FA, Bertoncello MR, Tillmann MAA, Menezes NL (2008) Pré-hidratação de sementes de ervilha e sua interferência na avaliação do potencial fisiológico. Revista Brasileira de Sementes 30(1):198207.

Custódio CC, Machado Neto NB, Ito HM, Vivan MR (2002) Efeito da submersão em água de sementes de feijão na germinação e no vigor. Revista Brasileira de Sementes 24(2):49-54.

Custódio CC, Neto NBM, Moreno ELC, Vuolo BG. (2009) Water submersion of bean seeds in the vigour evaluation. Revista Brasileira de Ciências Agrárias 4(3):261-266.

Dalchiavon FC.; NEVES, Graciele; HAGA, Kuniko I (2016) Efeito de stresse salino em sementes de Phaseolus vulgaris. Revista de Ciências Agrárias 39(3):404-412.

Dantas BF, Aragão CA, Caravariani C, Nakagawa J, Rodrigues JD (2000) Teste de alagamento para avaliação do vigor em sementes de milho. Revista Brasileira de Sementes 22(2):288-292.

Deuner C, Maia MS, Deuner S, Almeida AS, Meneghello GM (2011) Viabilidade e atividade antioxidante de sementes de genótipos de feijão-miúdo submetidos ao estresse salino. Revista Brasileira de Sementes 33(4):711-720.

Ferreira DF (2011) Sisvar: a computer statistical analysis system. Ciência e Agrotecnologia 35(6):1039-1042.

Gazola D, Zucareli C, Camargo M C (2014) Comportamento germinativo de sementes de cultivares de milho sob condições de hipóxia. Científica 42(3):224232.

Gazolla-Neto A, Aumonde TZ, Pedó T, Olsen D, Villela FA (2012) Níveis de umidade do solo de várzea e seus efeitos sobre a emergência e crescimento inicial de plântulas de soja. Informativo Abrates 22(2):28-31.
Kirsanova D, Zadorozhnayaa $O$, Krasheninnikov A, Komarova N, Popov A, Legina A (2013) Water toxicity evaluation in terms of bioassay with an Electronic Tongue. Sensors and Actuators 179:282-286.

Lima KL, Cavalcante LF, Feitosa-Filho JC (2001) Efeitos de fontes e níveis de salinidade da água de irrigação sobre a germinação e o crescimento da pinheira. Engenharia Agrícola 21(2):135-144.

Lopes JC, Macedo CMP (2008) Germinação de sementes de sob influência do teor de substrato e estresse salino. Revista Brasileira de Sementes 30(3): 79-85.

Marcos Filho $J$ (2015) Fisiologia de sementes de plantas cultivadas. Abrates. 660p.

Melloni MLG, Cruz FJR, Santos DMM, Souza LFG, Silva J, Saccini VAV, Monteiro JG (2012) Espermidina exógena atenua os efeitos do $\mathrm{NaCl}$ na germinação e crescimento inicial de leguminosas forrageiras. Revista Brasileira de Sementes 34(3):495-503.

Moraes GAF, Menezes NL (2003) Desempenho de sementes de soja sob condições diferentes de potencial osmótico. Ciência Rural 33(2):219-226.

Moterle LM, Lopes PC, Braccini AL, Scapim CA (2006) Germinação de Sementes e Crescimento de Plântulas de Cultivares de Milho-Pipoca Submetidas ao Estresse Hídrico e Salino. Revista Brasileira de Sementes 28(3):169-176.

Nakagawa J (1999) Teste de vigor baseado no desempenho das plântulas. In: Krzyzamowski FC, Vieira $\mathrm{RD}$, França Neto JB (ed.) Vigor de sementes: conceito e testes. Abrates. p.1-24.

Nunes AS, Lourenção ALF, Pezarico CR, Scalon SPQ, Gonçalves MC (2009). Fontes e níveis de salinidade na germinação de sementes de Crotalaria juncea $L$. Ciência e agrotecnologia 33(3):753-757.

Pedó T, Martinazzo EG, Aisenberg GA, Aumonde TZ, Villela FA, Antunes IF (2017) Crescimento de plantas e qualidade fisiológica de sementes de feijão sob alagamento do solo. Scientia Agraria Paranaensis 16(1):94-98.

Pereira MRR, Martins CC, Martins D, Silva RJN (2014) Estresse hídrico induzido por soluções de PEG e de $\mathrm{NaCl}$ na germinação de sementes de nabiça e fedegoso. Bioscience Journal 30(3):687-696.

Ramos TJN, Carvalho CJR, Souza CMA, Vasconcelos SS (2010) Alterações morfológicas e crescimento de duas espécies gramíneas sob alagamento. Revista de Ciências Agrárias 53(1):5-11. 
Richetti A. (2015) Viabilidade econômica da cultura da soja na safra 2015/2016, em Mato Grosso do Sul. Embrapa Agropecuária Oeste. 13 p.

Rosa TD, Pedó T, Martinazzo EG, Gehling VM, Aisenberg GR, Aumonde TZ, Villela FA (2015) Alagamento do solo: efeito no crescimento inicial da aveia branca (Avena sativa L.). Scientia Agraria Paranaensis 14(2):127-131.

Salisbury FB, Ross CW (1991) Plant physiology. 4.ed. Wadsworth. 682p.

Shu k, Qi Y, Chen F, Meng Y, Luo X, Shuai H, Zhou W, Ding J, Du J, Liu J, Yang F, Wang Q, Liu W, Yong T, Wang X, Feng Y, Yang W (2017) Salt Stress Represses Soybean Seed Germination by Negatively Regulating GA Biosynthesis While Positively Mediating ABA Biosynthesis. Frontier in Plant Science 8(1372): 1-12.

Silva R C, Grzybowski, CRS, Panobianco M (2016) Vigor de sementes de milho: influência no desenvolvimento de plântulas em condições de estresse salino. Revista Ciência Agronômica 47(3):491-499.

Soares MM, Santos Junior HC, Simões MG, Pazzin D, Silva LL (2015) Estresse hídrico e salino em sementes de soja classificadas em diferentes tamanhos. Pesquisa Agropecuária Tropical 45(4):370-378.
Taiz L, Zeiger E (2017) Fisiologia vegetal. 6.ed. Artmed. 888p.

Teixeira JR, Braccini AL, Sperandio D, Scapim CA, Schuster I, Viganó J (2008) Avaliação de cultivares de soja quanto à tolerância ao estresse hídrico em substrato contendo polietileno glicol. Acta Scientiarum Agronomy 30(2):217-223.

Toorchi M, Yukawa K, Nouri MZ, Komatsu S (2009) Proteomics approach for identifying osmotic-stressrelated proteins in soybeans roots. Peptides 30(12):2108-2117.

Vaz-de-Melo A, Santos LDT, Finoto EL, Dias DCFS, Alvarenga EM (2012) Germinação e vigor de sementes de milho-pipoca submetidas ao estresse térmico e hídrico. Bioscience Journal 28(5):687-695.

Viçosi KA, Ferreira AAS, Oliveira LAB, Rodrigues $F$ (2017) Estresse hídrico simulado em genótipos de feijão, milho e soja. Revista de Agricultura Neotropical 4(Suplemento 1):36-42.

Zabalza A, Dongen JTV, Froehlich A, Oliver SN, Faix B, Gupta KJ, Schmälzlin E, Igal M, Orcaray L, Royuela M, Geigenberger P (2008) Regulation of respiration and fermentation to control the plant internal oxygen concentration. Plant Physiology 149(2):1087-1098. 